\title{
Politik Uang Dalam Pemilu Ditinjau Dari Perspektif Yuridis Sosiologis
}

\author{
Retna Susanti \\ Magister Hukum Fakultas Hukum Universitas Islam Indonesia Yogyakarta Indonesia \\ Jln. Cik Di Tiro No. 1 Yogyakarta Indonesia \\ retnasusanti1912@gmail.com
}

\begin{abstract}
This study aims to analyze the formulation of money politics criminal acts in the Election Law and examine law enforcement on money politics from a sociological perspective. The choice of the sociological juridical approach method is intended to photograph the application and study of the relationship between legal aspects and non-legal aspects in the operation of law in society. Gaining votes in elections can be reached with non-monetary power, such as through family, social and economic networks, but the portion of the determination is more with money politics. The results of the study conclude that the formulation of money politics in the Election Law is not progressive enough so that it needs to be reformed. In addition, from a sociological perspective, the effectiveness of resolving election crimes related to money politics is largely determined by public awareness and participation.
\end{abstract}

Key Words: Election criminal law; law enforcement; money politics

\begin{abstract}
Abstrak
Penelitian ini bertujuan untuk menganalisis perumusan tindak pidana politik uang dalam UndangUndang Pemilu dan mengkaji penegakan hukum atas tindak pidana politik uang dari perspektif sosiologis. Pemilihan metode pendekatan hukum yuridis sosiologis dimaksudkan untuk memotret penerapan dan pengkajian hubungan aspek hukum dengan aspek non hukum dalam bekerjanya hukum di masyarakat. Pendulangan suara dalam pemilu dapat dijangkau dengan kekuatan non uang, seperti melalui jaringan keluarga, sosial dan ekonomi, tetapi porsi penentuan lebih banyak dengan politik uang. Hasil penelitian menyimpulkan bahwa perumusan tindak pidana politik uang dalam Undang-Undang Pemilu tidak cukup progresif sehingga perlu dilakukan pembaharuan. Selain itu, ditinjau dari perspektif sosiologis, efektivitas penyelesaian tindak pidana pemilu terkait politik uang, banyak ditentukan oleh kesadaran dan partisipasi masyarakat.
\end{abstract}

Kata-kata Kunci: Politik uang; hukum pidana pemilu; penegakan hukum 


\section{Pendahuluan}

Indonesia menyelenggarakan Pemilu serentak untuk pertama kali pada 2019, tepatnya pada 17 April 2019. Penyelenggaraan pemilu tersebut merujuk pada Putusan Mahkamah Konstitusi yang mengabulkan sebagian gugatan uji materi atas Undang-Undang No. 42 Tahun 2008 tentang Partai Politik yang selanjutnya disebut Undang-Undang Partai Politik. Pemilu serentak (concurrent election) secara sederhana dapat didefinisikan sebagai sistem pemilu yang melangsungkan beberapa pemilihan pada satu waktu secara bersamaan.

Kontestasi politik di Indonesia dalam memperebutkan kursi kekuasaan eksekutif dan legislatif masih marak dengan isu politik uang. Politik uang sendiri sebenarnya merupakan istilah sosiologis ${ }^{1}$ yang telah digunakan secara luas sejak tahun 1990-an. Istilah ini digunakan untuk menggambarkan perilaku kandidat yang telah membagi-bagikan uang atau barang kepada para pemilih, dan menyuap pejabat penyelenggara pemilu. Dapat pula diartikan sebagai praktik yang merujuk pada distribusi uang atau terkadang barang dari kandidat kepada pemilih pada saat pemilu. ${ }^{2}$

Ramlan Surbakti ${ }^{3}$ memaparkan bahwa ada dua hal penting terkait pengaturan tindak pidana dalam pemilu. Pertama, tindak pidana pemilu ditujukkan untuk melindungi peserta pemilu, lembaga penyelenggara pemilu, pelaksana pemilu dan pemilih dari berbagai tindakkan pelanggaran pemilu yang merugikan. Kedua, tindak pidana pemilu ditujukan untuk menegakkan tertib hukum dalam penyelenggaraan pemilu. Penegakan hukum terhadap tindak pidana politik uang bukanlah masalah yang mudah. Menurut Satjipto Rahardjo, ${ }^{4}$ masalah penegakan hukum merupakan persoalan yang tidak sederhana, bukan saja karena kompleksitas sistem hukum itu sendiri, tetapi juga rumitnya jalinan hubungan antara sistem hukum dengan sistem sosial, politik, ekonomi, dan budaya masyarakat.

\section{Rumusan Masalah}

Berdasarkan latar belakang diatas dapat dirumuskan beberapa permasalahan berikut: pertama, bagaimana perumusan tindak pidana politik uang

${ }^{1}$ Topo Santoso, Kuliah Umum Tindak Pidana Pemilu Di Indonesia,disampaikan di Gedung Pasca Sarjana UII, Yogyakarta,9 Februari 2019

2 Edward Aspinall dan Mada Sukmajati, Politik Uang Di Indonesia, Patronase dan Klientelisme pada Pemilu Legislatif, Cetakan Pertama, Penerbit PolGov, Yogyakarta, 2015, hlm. 2-3

${ }^{3}$ Ramlan Surbakti, dkk, Penanganan Pelanggaran Pemilu, ,Cetakan Kelimabelas, Kerjasama Kemitraan, Kingdom of The Netherlands and Danish International Development Agency, Jakarta, 2011, hlm. 16

4 Satjipto Rahardjo, Penegakan Hukum Suatu Tinjauan Sosiologis, Cetakan Pertama, Genta Publishing, Yogyakarta, 2009, hlm. viii-ix. 
dalam Undang-Undang Pemilu? Kedua, bagaimana penegakan hukum terhadap politik uang dalam pemilu ditinjau dari perspektif sosiologis?

\section{Tujuan Penelitian}

Penelitian ini bertujuan sebagai berikut, pertama, untuk menganalisis perumusan tindak pidana politik uang dalam Undang-Undang Pemilu. Kedua, untuk mengkaji penegakan hukum terhadap politik uang dalam pemilu ditinjau dari perspektif sosiologis.

\section{Metode Penelitian}

Penelitian ini menggunakan jenis penelitian hukum yuridis sosiologis (social legal approach) yang dimaksudkan sebagai pengkajian hubungan aspek hukum dengan aspek non hukum dalam bekerjanya hukum di masyarakat. Penelitian hukum sosiologis atau empiris hendak mengadakan pengukuran terhadap peraturan perundang-undangan tertentu mengenai efektifitasnya, maka definisidefinisi operasional dapat diambil dari peraturan perundang-undangan tersebut. ${ }^{5}$ Analisis penelitian ini bersifat diskriptif kualitatif,, adapun tempat penelitian adalah Kabupaten Bantul data yang digunakan dalam penelitian ini adalah data primer yang di dapat dari penelitian lapangan, dengan metode wawancara kepada para penyelenggara pemilu, tim sukses kandidat, kandidat peserta pemilu, dan penerima politik uang. Sedangkan data sekunder, diperoleh dari bahan-bahan pustaka.

\section{Hasil Penelitian dan Pembahasan}

\section{Perumusan Tindak Pidana Politik Uang dalam Undang-Undang Pemilu}

Elemen penting dalam proses pendidikan dan pesta demokrasi adalah pembentukan kepercayaan rakyat terhadap pemilu. Jika rakyat tidak merasa terlibat secara bebas untuk mengelola pilihan politik, mendapat informasi memadai sesuai keperluan dan tujuannya, sebagaimana hak pilihnya dihormati, proses pemilu menjadi tidak signifikan. Di samping itu, para kandidat harus mendapat kesempatan yang sama untuk memenangi suara pada tingkat berkompetisi yang fair. Para kandidat juga harus merasakan keterlibatan dalam proses dan menghargai hasil pemilu dengan cara-cara yang beradab, jujur, dan tidak menggunakan kuasa uang untuk mendapatkan kursi wakil rakyat.

Daulat uang menjadi praktek new normal yang menentukan irama permainan dalam kompetisi elektoral di Indonesia. Terlepas dari fakta bahwa

\footnotetext{
${ }^{5}$ Soerjono Soekanto, Pengantar Penelitian Hukum, UI Pers, Jakarta, 2010, hlm. 53.
} 
politik uang secara formal illegal, namun lama-kelamaan dianggap menjadi transaksi normal selama pemilu, dan jarang dituntut secara hukum. Oleh karena politik uang sudah dianggap lumrah, para politisi menolak untuk dijadikan sebagai satu-satunya kambing hitam dan berdalih bahwa pemilih justru tidak lagi melihat pemilu sebagai jendela kesempatan untuk mengepresikan preferensi politik mereka, tetapi sebagai musim panen uang (season of money). ${ }^{6}$ Peran dan fungsi uang bagi penyelenggara pemilu sangat terkait dengan pembiayaan penyelenggaraan pemilu, sedangkan dari sisi pemilih uang berfungsi sebagai alat untuk mempengaruhi keputusan pemilih misalnya dalam bentuk pembelian suara. $^{7}$

Politik uang merupakan salah satu tindak pidana dalam pemilu. Tindak Pidana Pemilu menurut Topo Santoso dan Ida Budiati ${ }^{8}$ adalah setiap tindakan/perbuatan (aktif/pasif) yang melanggar ketentuan dalam tahapantahapan penyelenggaraan pemilu yang diancam dengan sanksi pidana dalam undang-undang pemilu. Tindak pidana politik uang diatur dalam Pasal 280 ayat (1) Undang-Undang Pemilu yang berbunyi "Pelaksana, Peserta, dan Tim Kampanye Pemilu dilarang: j. Menjanjikan atau memberikan uang atau materi lainnya kepada Peserta Kampanye Pemilu."

Selain itu, diatur pula dalam Pasal 523 yang berbunyi:

(1)Setiap pelaksana, peserta, dan atau tim kampanye, pemilu yang dengan sengaja menjanjikan atau memberikan uang atau materi lainnya sebagai imbalan kepada peserta kampanye pemilu secara langsung ataupun tidak langsung sebagaimana dimaksud dalam Pasal 280 ayat (1) huruf $j$ dipidana dengan pidana penjara paling lama 2 (dua) tahun dan denda paling banyak Rp.24.000.000,- ( dua puluh empat juta rupiah).

(2)Setiap pelaksana, peserta, dan/ atau tim kampanye pemilu yang dengan sengaja pada masa tenang menjanjikan atau memberikan imbalan uang atau materi lainnya kepada pemilih secara langsung ataupun tidak langsung sebagaimana dimaksud dalam Pasal 278 ayat (2) dipidana dengan pidana penjara paling lama 4 (empat) tahun dan denda paling banyak Rp.48.000.000,- (empat puluh delapan juta rupiah)

(3)Setiap orang yang dengan sengaja pada hari pemungutan suara menjanjikan atau memberikan uang atau materi lainnya kepada pemilih untuk tidak menggunakan hak pilihnya atau memilih peserta pemilu tertentu dipidana dengan pidana penjara paling lama 3 (tiga) tahun dan denda paling banyak Rp.36.000.000,00 (tiga puluh enam juta rupiah).

\footnotetext{
${ }^{6}$ Burhanuddin Muhtadi, Op. Cit., hlm. 87.

7 Alexander Herbert E, Money and Politics, Rethinking Conceptual Framework, Cambridge University Press, Cambridge, 1989, hlm. 9-23.

8 Topo Santoso dan Ida Budiati, Pemilu Di Indonesia Kelembagaan, Pelaksanaan, dan Pengawasan, Sinar Grafika, Jakarta, 2019, hlm. 283
} 
Pasal di atas mengatur tentang elemen-elemen politik uang seperti pada masa kampanye, masa tenang dan pada saat pemungutan suara berlangsung; Pada ayat (1) dan (2) tindak pidana yang dilakukan oleh pelaksana, peserta dan atau tim kampanye Pemilu, sedangkan elemen pada ayat (3) ditujukan kepada siapa saja atau setiap orang yang melakukan tindak pidana politik uang pada saat pemungutan suara dilakukan. Ancaman pidana penjara dimasing - masing ayat berbeda, ayat (1) ancaman pidana penjara 2 tahun, ayat (2) ancamannya 4 tahun, sedangkan ayat (3) ancaman pidananya 3 tahun. Ini berarti bahwa ancaman pidana terberat ditujukan kepada pelaku politik uang yang melakukan perbuatan pidananya di masa tenang dibandingkan apabila dilakukan di masa kampanye dan masa pemungutan suara. Sedangkan untuk besaran denda, paling banyak apabila dilakukan pada masa tenang, daripada masa pemungutan suara dan kampanye. ${ }^{9}$

Pasal tindak pidana politik uang berupa mahar politik dan sumbangan dana kampanye terkait pencalonan presiden dan wakil presiden diatur dalam Pasal 228 yang berbunyi:

(1)Partai Politik dilarang menerima imbalan dalam bentuk apapun pada proses pencalonan presiden dan wakil presiden;

(2)Dalam hal Partai Politik terbukti menerima imbalan sebagaimana dimaksud pada ayat (1) partai politik yang bersangkutan dilarang mengajukan calon pada periode berikutnya;

(3)Partai politik yang menerima imbalan sebagaimana dimaksud pada ayat (2) harus dibuktikan dengan putusan pengadilan yang telah memperoleh kekuatan hukum tetap;

(4)Setiap orang atau lembaga dilarang memberikan imbalan kepada partai politik dalam bentuk apapun dalam proses pencalonan presiden dan wakil presiden.

Pasal tersebut dengan jelas melarang adanya pemberian dan penerimaan mahar politik, baik dari maupun kepada partai politik dalam penentuan calon presiden dan wakil presiden. Pasal 228 memakai kata "imbalan" dalam mendiskripsikan mahar politik, yang artinya upah sebagai pembalas jasa, atau honorarium atau balasan (berupa pujian, hukuman dan sebagainya) atas tindakkan yang telah dilakukan. ${ }^{10}$. Sedangkan Pasal 325 jo 327 menggunakan istilah "sumbangan", yang artinya memberikan bantuan atau sokongan yang pada umumnya bersifat secara fisik oleh perorangan atau badan hukum, yang bersifat

${ }^{9}$ Hariman Satria, "Politik Hukum Tindak Pidana Politik Uang Dalam Pemilihan Umum Di Indonesia", JurnalAntikorupsiINTEGRITAS,5(1),1-14e-ISSN:2615-7977/2477-118X DOI:https://doi.org/10.32697/ integritas.v5i1.342@Komisi Pemberantasan Korupsi

${ }^{10}$ Kamus Besar Bahasa Indonesia (KBBI) 
sukarela dengan tanpa adanya imbalan yang bersifat keuntungan kepada orang lain. ${ }^{11}$

Dari pasal tersebut dapat diketahui bahwa sumbangan dana kampanye merupakan sumbangan yang diberikan khusus untuk membiayai kampanye yang bisa didapat dari capres maupun cawapres itu sendiri, parpol dan gabungan parpol maupun sumbangan lain. Artinya sumbangan dalam pembiayaan kampanye parpol, gabungan parpol dapat menerima sumbangan dana dari perseorangan, kelompok, perusahaan, atau badan usaha non pemerintah, yang bentuknya ditentukan berupa uang yang tidak boleh besarannya melebihi Rp. 2.500.000.000,00, barang, ataupun jasa, yang harus dilaporkan ke KPU dengan mencantumkan identitas yang jelas.

Sanksi dengan jelas ditujukan bukan kepada pelaku mahar politik, karena dalam undang-undang pemilu dibedakan antara sumbangan dana kampanye dan mahar politik, sedangkan pasal tersebut secara tegas ditujukan kepada pelanggar Pasal 327 ayat (1) dan Pasal 331 ayat (2) UU Pemilu. Oleh karena itu dapat diambil kesimpulan bahwa pemberi dan penerima mahar politik terhadap capres dan cawapres, tidak dapat dijatuhi sanksi pidana, dan tidak diatur dalam ketentuan pidana sehingga tidak bisa ditindak lanjuti dengan penanganan tindak pidana pemilu. Mahar politik juga tidak dapat dimasukkan sebagai pelanggaran administrasi karena bukan bagian dari proses pelanggaran tata cara, prosedur, atau mekanisme yang berkaitan dengan administrasi pelaksanaan pemilu.

Tidak ada sanksi bagi pemberi mahar politik sedangkan sanksi bagi Parpol yang menerima mahar politik diatur dalam Pasal 228 ayat (2) UU Pemilu, berupa larangan mengajukan calon presiden dan wakil presiden pada periode berikutnya, dan tidak ada sanksi yang lain seperti sanksi pidana. Pembuktian mahar politik yang diterima Parpol sangat sulit dibuktikan dan hampir mustahil bisa dilakukan karena biasanya deal- deal mahar politik sudah dilakukan sebelum proses tahapan resmi yang ditetapkan penyelenggara pemilu atau dilakukan diruang-ruang rahasia yang tidak setiap orang mampu memasuki dan menjangkaunya. Secara otomatis akan relatif mudah menghindar dari pengawasan Bawaslu.

\section{Tinjauan Sosiologis Penegakan Hukum Politik Uang dalam Pemilu}

Sosiologi hukum membuka mata dan mengoreksi peran manusia dalam berhukum. Hukum yang diusung oleh kaum positivistik hanya dipandang sebagai teks dan mengeliminasi peran manusia. Apabila hukum bertujuan untuk mewujudkan kesesuaian antara apa yang diatur dengan apa yang terjadi dalam

11 Wikipedia Bahasa Indonesia 
kenyataan di masyarakat, maka kepiawaian para pembuat hukum dalam berperspektif mengakomodir keadaan masyarakat baik dari segi budaya, agama, adat dan lain sebagainya, sangat dibutuhkan, supaya masyarakat tidak merasa asing dengan hukum yang harus ditaatinya.

Sosiologi hukum senantiasa menguji kesahihan empiris dari suatu peraturan yang dikeluarkan, tentang bagaimana peraturan tersebut dalam kenyataan. Pendekatan normatif menerima apa saja yang tertera dalam peraturan, sedangkan pendekatan sosiologis senantiasa menguji dan dan menghadapkannya dengan realitas di lapangan. ${ }^{12}$

Pada akhirnya gambar hukum yang sebenarnya tercermin pada perilaku hukum, bukan pada undang-undangnya. Begitu juga tindak pidana pemilu terutama politik uang, tercermin bahwa masyarakat sendiri, menerima dengan suka cita adanya perilaku pelanggaran pidana tersebut, bahkan mau menutupinya, walaupun undang-undang pemilu nyata-nyata melarangnya, dengan sanksi pidana yang lumayan berat.

Politik uang yang terjadi di Kabupaten Bantul menjadi fenomena yang tidak bisa dilepaskan dengan budaya patronklien di Indonesia. Patronklien adalah produk sosial budaya dimana kelompok yang memiliki keistimewaan tertentu memberikan uang atau keuntungan sebagai imbalan atas loyalitas pengikutnya. ${ }^{13}$ Pintu masuk lain bagi adanya politik uang di wilayah ini adalah lemahnya party $I D$, yang berakibat pada banyaknya pemilih yang tidak loyal (swing voters) pada suatu partai tertentu. Faktor-faktor tersebut menimbulkan akibat pada pilihan masyarakat yang mendasarkan pilihan politik di bilik suara berdasarkan pada rasionalitas ekonomi dan perhitungan utung rugi sehingga mereka akan memilih partai politik atau calon yang bisa memberikan keuntungan secara langsung.

Adapun penulis membagi berdasarkan ciri-ciri umum yang biasa dipakai kandidat atau tim sukses dalam menentukan jenis pemilih:

Pertama, masyarakat yang menganggap dan punya pandangan bahwa jual beli suara sebagai hal yang wajar dan umum terjadi, bahkan masyarakat dan beberapa tim sukses menganggap sebagai tradisi dalam pemilu, sehingga ketika ada implikasi hukum apabila melakukan politik uang karena merupakan perbuatan illegal, mereka yakin penjara tidak akan menjerat mereka, karena penjara akan penuh apabila praktek politik uang akan diproses hukum. Istilah NPWP atau "Nomor Piro Wani Piro" merupakan bahasa lugas untuk

12 Donald Black, The Behavior of Law,New York, Penguinn Books, 1983 diterjemahkan Th.Bambang Murtianto dan Stevano Brando Thoviano,Cetakan Pertama,Pelangi Cendekia, Jakarta, 2020, hlm.xix

13 Burhanuddin Muhtadi, "Politik Uang dan Dinamika Elektoral di Indonesia : Sebuah Kajian Awal Interaksi Antara Party ID dan Patron Klien”, Jornal Penelitian Politik, Vol. 10 No. 1 Juni 2013, ejournal.politik.lipi.go.id $>$ jpp 
menawarkan suara, biasanya pemilih ini disebut dengan istilah massa mengambang. Politik uang akan meningkat untuk karakter pemilih ini menjelang pencoblosan

Kedua, masyarakat yang digalang oleh penggurus RT, PKK, Takmir Masjid atau tokoh masyarakat, merupakan pioner dalam ajang mobilisasi warga guna memilih kandidat. Pola yang diterapkan kandidat dengan menggunakan cara ini adalah "sistem ijon", salah satu istilah dalam transaksi jual beli hasil tanaman yang masih dalam keadaan hujau, dan belum dipetik dari batangnya atau pohonnya. ${ }^{14}$ Kandidat mengadakan kontrak jual beli suara jauh-jauh hari sebelum tahapan kampanye dimulai dengan memberikan sejumlah uang, perbaikan sarana kampung,dan lain-lain, dengan imbalan masyarakat di dusun tersebut pada saat pencoblosan akan memilih kandidat tersebut dengan dikoordinir oleh pengurus/tokoh masyarakat, takmir, ketua RT dan ketua PKK. Penerapan sistem ini relatif aman bagi kandidat karena pemakaian politik uang dilakukan jauh hari sebelum tahapan pelaksanaan kampanye pemilu, sehingga kandidat bisa melenggang bebas dari jeratan pasal pidana politik uang, karena aturan hukumnya hanya bisa menjerat peserta pada saat tahapan kampanye. Hasil politik uang dari kandidat digunakan untuk kesejahteraan bersama, seperti untuk seragam ibu-ibu PKK atau pengajian, pembelian alat-alat kelengkapan RT seperti tenda, kursi dan lain-lain, sampai perbaikan jalan kampung.

Ketiga, Pemilih Party ID atau identifikasi pemilih terhadap partai. Politisi dan tim sukses lebih memilih pada pemilih basis ini, karena lebih bisa diandalkan dalam meraup suara dibandingkan dengan pemilih mengambang yang belum tentu memberikan suaranya, dan kadang "tidak tahu berterimakasih"15. Para kandidat yang telah beberapakali menjadi anggota DPD, DPR RI,DPRD TK I dan II, biasanya telah memiliki tabungan pemilih loyal yang mereka rawat selama menjabat, dengan membantu setiap kebutuhan konstituen misalnya perbaikan atau pengerasan jalan, poging, acara tujuh belasan atau kegiatan keagamaan dan lain sebagainya, biasanya kandidat juga rajin datang setiap masa reses dan menggunakan dana aspirasi ataupun dana pribadi untuk merawat konstituen. Karena itu loyalitas pada partai ini tidak tergantung pada politik uang yang mungkin dibagikan oleh kandidat lain, bahkan ada jargon yang dipasang di jalan kampung "tompo duite, pilih liyane". Pemilih jenis ini menjadi sasaran kandidat, dengan dasar pemikiran di tengah ketidak pastian yang tinggi dan besaran resiko,

\footnotetext{
14 id.m.wiktionary.org

15 Burhanuddin Muhtadi, Kuasa Uang: Politik Uang dalam Pemilu Pasca Orde Baru, Cetakkan Pertama, Kepustakaan Populer Gramedia, Jakarta, 2020, hlm. 75
} 
daripada mengejar pemilih yang tidak pasti lebih baik merawat dan mengamankan yang sudah ada.

Ditemukannya praktek politik uang disetiap perhelatan pemilu menjadikan perilaku ini merupakan agenda tetap dalam kontestasi politik, sehingga berimbas pada tingginya biaya politik yang harus ditanggung oleh kontestan. ${ }^{16}$ Para penyelenggara pemilu di Bantul menyadari bahwa praktek politik uang ini marak selama pemilu serentak 2019 di Bantul, tetapi mereka mengalami kesulitan dalam membuktikannya, baik karena keterbatasan sumberdaya manusia maupun kurangnya alat bukti, karena praktek jual beli suara melibatkan tiga aktor yaitu peserta, penyelenggara, dan pemilih. Pengawas Pemilu pun mengakui bahwa penemuan tindak pidana politik uang yang berhasil mereka jerat, diakui hanya merupakan suatu fenomena gunung es. ${ }^{17}$

Penegakan hukum dalam hal politik uang bukanlah suatu pekerjaan yang mudah karena mempunyai hubungan timbal balik yang erat dengan masyarakat. Kerumitan susunan badan-badan penegak hukum meningkat seiring interaksinya dengan masyarakat yang menjadi cukup rumit, oleh karena itu dalam penegakan hukum ini, tidak dapat diabaikan faktor lingkungan sosial tempat penegakkan hukum tersebut dijalankan. ${ }^{18}$

Terkait permasalahan tindak pidana politik uang yang sudah sangat terstruktur, sistematis, dan masif yang menjadi "penyakit" disetiap pemilu, membutuhkan peran Bawaslu sebagai pengawas pemilu, kepolisian, kejaksaan, dan hakim pengadilan untuk mengambil langkah progresif dalam membebaskan dari kerangkeng hukum yang selama ini hanya berdasarkan pada tekstual dan harfiah undang-undang pemilu semata. Dibutuhkan suatu rekomendasi konsep perbaikan peraturan atau hukum pidana yang bisa melengkapi dan menyempurnakan Undang-Undang Pemilu yang ada, guna mempersempit ruang gerak para pelaku politik uang.

Kehidupan hukum terletak pada praktek penggunaannya atau enforcement, dan efektifitas hukum yang bekerja dengan bahan kenyataan yang terjadi dalam masyarakat. Berdasarkan penelitian teks undang-undang dan konteks pelaksanaan undang-undang di masyarakat, berikut konsep dari perspektif yuridis maupun sosiologis, yang dapat penulis sampaikan terkait dengan undang-undang pemilu:

16 Robi Cahyadi Kurniawan, Dedy Hermawan, "Strategi Sosial Pencegahan Politik Uang Di Indonesia", JurnalAntikorupsiINTEGRITAS,5(1),29-41e-ISSN/p-ISSN:2615-7977/2477-118XDOI:

https://doi.org/10.32697/integritas.v5i1.338 CKomisi Pemberantasan Korupsi

${ }_{17}$ Wawancara dengan Komisioner Bawaslu Kabupaten Bantul, di Kantor Bawaslu Bantul, 10 Mei 2020

${ }^{18}$ Satjipto Rahardjo, Penegakan Hukum Progresif, Penerbit Buku Kompas, Jakarta, 2009, hlm. 23. 
Pertama, masa tenggang penanganan tindak pidana pemilu. Pelaporan pelanggaran tindak pidana politik uang ditingkat yang paling rendah adalah Panitia Pengawas Kecamatan (Panwascam), kepada Bawaslu Kabupaten Kota atau jenjang diatasnya. ${ }^{19}$ Seharusnya pelaporan terjadinya tindak pidana bisa dibuka dan dilakukan oleh siapa saja, kapan saja, dan dimana saja, yang ada pelanggaran pidana pemilunya tidak dibatasi pada orang tertentu. Menurut Eddy O.S Hiariej, dalam tindak pidana pemilu sering terjadi secara concursus idealis dengan tindak pidana, yang berkaitan dengan pemilu yang diatur dalam KUHP. ${ }^{20}$ Oleh karena itu suatu perbuatan pidana yang terjadi selama pemilu yang sedang dalam proses penyidikan dan penuntutan yang melampaui batas waktu sebagaimana diatur dalam Undang-Undang Pemilu, tidak serta merta perkara tersebut gugur walaupun perhelatan pemilu sudah berakhir.

Kedua, teknis perumusan undang-undang terkait subyek pidana politik uang seharusnya tidak dibatasi orang tertentu. Pengaturan politik uang dalam undangundang pemilu disetiap tahapannya berbeda-beda, baik terkait subyek maupun ketentuan pidananya. Subyek pelaku politik uang pada tahapan kampanye ditujukan pada pelaksana, peserta, dan tim kampanye pemilu. ${ }^{21}$ Sedangkan pada masa tenang pelaksana, peserta, dan atau tim kampanye presiden/wakil presiden. ${ }^{22}$ Sedangkan untuk tahapan pemungutan suara subyek pelaku politik uang menjadi 'setiap orang' tanpa dibatasi kualitas atau latar belakang pelaku politik uang. ${ }^{23}$ Selain persoalan subyek pelaku, terkait sanksi pidana penjara dan besaran denda juga berbeda-beda.

Ketiga, pelaporan dan pengawasan pemilu dibuka bagi masyarakat secara luas. Bawaslu sebagai pengawas pemilu harus selalu meningkatkan dan memperkuat jajarannya dalam hal kemampuan melaksanakan pengawasan. Tetapi Bawaslu secara kelembagaan memiliki sumberdaya manusia dan pendanaan yang terbatas, oleh karena itu harus membuka ruang dan memaksimalkan partisipasi publik dalam melakukan pencegahan dan pengawasan dalam melawan politik uang. Efektivitas penyelesaian tindak pidana pemilu banyak ditentukan oleh kesadaran dan partisipasi masyarakat dalam penegakkan hukum pidana pemilu khususnya politik uang.

Keempat, memperkuat upaya pencegahan terjadinya politik uang. Modus politik uang saat ini semakin beragam dan berkembang, cara baru yang

19 Perbawaslu RI Nomor.7 Tahun 2018 tentang Penanganan Temuan dan Laporan Pelanggaran Pemilihan Umum

${ }^{20}$ Eddy O.S Hiariej, Pemilukada Kini dan Masa Datang Perspektif Hukum Pidana, Konstitusi Press Jakarta, 2012, hlm. 184

${ }^{21}$ Pasal 280 ayat (1) huruf j UU No.7 Tahun 2017 tentang Pemilu

22 Pasal 278 ayat (2)

23 Pasal 515 Undang-Undang Pemilu 
dilakukan kandidat seperti, pemberian asuransi kecelakaan, pemberian e-money, penarikan uang untuk politik uang dilakukan jauh hari sebelum pemilu, sehingga tidak perlu dimasukkan dalam laporan dana kampanye, dan pemberian jasa yang dilakukan jauh hari sebagai bentuk pengikat suara masyarakat. Oleh karena itu dibutuhkan sinergitas antara pemerintah, penyelenggara pemilu, dan masyarakat harus terus didorong lewat publikasi, sehingga bisa meredam tindak pidana politik uang yang dilakukan oleh para kandidat dalam upaya meraih suara dan empati rakyat.

Kelima, kurangnya perhatian pembuat undang-undang terhadap persoalan keadilan pemilu. Pembahasan yang menyangkut keadilan pemilu termasuk didalamnya pidana pemilu yang memiliki kekuatan untuk menjatuhkan sanksi bagi yang melanggar, kurang mendapatkan perhatian dan porsi yang cukup, sehingga wajar apabila banyak sekali celah yang belum diatur, karena kerangka hukumnya memang tidak cukup mendukung untuk terwujudnya penegakkan hukum pemilu. Rumusan hukum pidana harus didasari pertimbangan matang dan harmonisasi yang baik, tidak hanya "terkesan" melanggengkan kekuasaan, lebih mengutamakan elit politik, daripada mengedepankan hakekat keadilan.

\section{Penutup}

Perumusan tindak pidana politik uang dalam Undang-Undang Pemilu tidak cukup progresif bila dibandingkan dengan UU No. 10 Tahun 2016 tentang Pilkada yang bisa menjerat secara hukum pelaku politik uang, baik pemberi maupun penerima. Dalam Undang-Undang Pemilu yang dapat dihukum hanya tim sukses yang terdaftar di KPU dan hukuman pun murni pidana sehingga Bawaslu tidak memiliki kewenangan untuk memberi sanksi administratif kepada pelaku politik uang. Kerangka hukum Undang-Undang Pemilu tidak cukup mendukung untuk terwujudnya penegakkan hukum pemilu. Penyelenggaraan pemilu didominasi oleh para pembuat kebijakan yang sekaligus merupakan peserta pemilu sehingga regulasi dibuat sedemikian rupa, yang tentu saja akan menguntungkan secara langsung maupun tidak langsung bagi para pembuat regulasi tersebut.

Efektivitas penegakan tindak pidana pemilu khususnya politik uang banyak ditentukan oleh kesadaran dan partisipasi masyarakat dalam penegakkan hukumnya. Kesadaran dan partisipasi tersebut berakar dari budaya hukum masyarakat itu sendiri baik yang berupa kepercayaan, kebiasaan, opini, cara bertindak baik penegak hukum maupun masyarakat tentang hukum, dan berbagai fenomena yang berkaitan dengan hukum. Munculnya desa-desa anti politik uang yang diinisiasi masyarakat bekerjasama dengan pemerintah desa yang memiliki jaringan struktural ke bawah seperti Kelompok PKK, Pedukuhan, 
RT dan RW, serta kelompok-kelompok masyarakat, diharapkan akan mendorong pemahaman dan kesadaran masyarakat akan bahaya politik uang. Sinergitas antara pemerintah, penyelenggara pemilu, dan masyarakat harus terus didorong lewat publikasi sehingga bisa menjadi contoh bagi masyarakat dan desa lain dalam upaya meredam tindak pidana politik uang yang dilakukan oleh para kandidat dalam upaya meraih suara dan empati rakyat.

\section{Daftar Pustaka}

\section{Buku}

Edward, Aspinall dan Sukmajati Mada,Politik Uang Di Indonesia, Patronase dan Klientelisme pada Pemilu Legislatif 2014, Cetakan Pertama, Penerbit PolGov, Yogyakarta, 2015.

Herbert, Alexander E, Money and Politics, Rethinking Conceptual Framework, Cambridge Univercity Press, Cambridge, 1989

Muhtadi, Burhanuddin, Kuasa Uang: Politik Uang dalam Pemilu Pasca Orde Baru, Cetakkan Pertama, Kepustakaan Populer Gramedia, Jakarta, 2020.

O.S. Hiariej, Eddy, Pemilukada Kini dan Masa Datang Perspektif Hukum Pidana, Konstitusi Press, Jakarta, 2012.

Rahardjo Satjipto, Penegakan Hukum Suatu Tinjauan Sosiologis, Cetakan Pertama, Genta Publishing, Yogyakarta, 2009.

Penegakan Hukum Progresif, Penerbit Buku Kompas, Jakarta, 2009.

Santoso, Topo, dan Budiati Ida, Pemilu Di Indonesia Kelembagaan, Pelaksanaan, dan Pengawasan, Cetakan Pertama, Sinar Grafika, Jakarta,2019.

Surbakti, Ramlan, dkk, Penanganan Pelanggaran Pemilu, Cetakan Kelimabelas, Buku Kerjasama Kemitraan, Kingdom of The Netherlands and Danish International Development Agency, Jakarta, 2011.

Soekanto, Soerjono, Pengantar Penelitian Hukum, UI Perss, Jakarta, 2010.

\section{Jurnal}

Cahyadi Kurniawan, Robi, dan Hermawan, Dedy, "Strategi Sosial Pencegahan Politik Uang Di Indonesia",JurnalAntikorupsiINTEGRITAS,5(1),29-41eISSN/p-ISSN:2615-7977/2477118X DOI: https://doi.org/10.32697/ integritas.v5i1.338 @Komisi Pemberantasan Korupsi

Muhtadi, Burhanuddin "Politik Uang dan Dinamika Elektoral di Indonesia : Sebuah Kajian Awal Interaksi Antara Party ID dan Patron Klien", Jornal Penelitian Politik, Vol. 10 No.1 Juni 2013,ejournal.politik.lipi.go.id>jpp

Satria,Hariman,"Politik Hukum Tindak Pidana Politik Uang Dalam Pemilihan Umum $\mathrm{Di} \quad$ Indonesia",JurnalAntikorupsiINTEGRITAS,5(1),1-14e-ISSN:26157977/2477-118X DOI:https://doi.org/10.32697/integritas.v5i1.342@ KomisiPemberantasan Korupsi 


\section{Makalah/ Pidato}

Santoso, Topo, Kuliah Umum Tindak Pidana Pemilu Di Indonesia, yang disampaikan di Gedung Pasca Sarjana UII, Yogyakarta,9 Februari 2019.

\section{Peraturan Perundang-Undangan}

Undang-Undang Nomor 7 Tahun 2017 tentang Pemilihan Umum, Lembaran Negara Republik Indonesia Tahun 2017, Tambahan Lembaran Negara RI Nomor 6109.

\section{Peraturan Bawaslu RI}

Peraturan Bawaslu RI Nomor.7 Tahun 2018 tentang Penanganan Temuan dan Laporan Pelanggaran Pemilihan Umum

\section{Wawancara}

Wawancara dengan Komisioner Bawaslu Kabupaten Bantul, di Kantor Bawaslu Bantul,10 Mei 2020

\section{Internet}

Kamus Besar Bahasa Indonesia (KBBI)

\section{Wikipedia Bahasa Indonesia}

id.m.wiktionary.org 